\title{
Export-Led Growth in East Asia: Lessons for Europe's Transition Economies
}

Ari Kokko (Ari.Kokko@hhs.se, arkokko@abo.fi)

\section{Approved by}

János Gács (gacs@iiasa.ac.at)

Project Leader, Economic Transition and Integration

October 2001 Institute, its National Member Organizations, or other organizations supporting the work. 


\section{Contents}

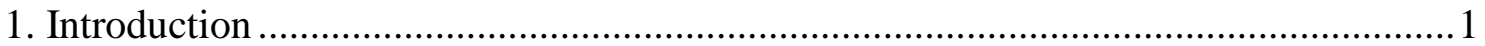

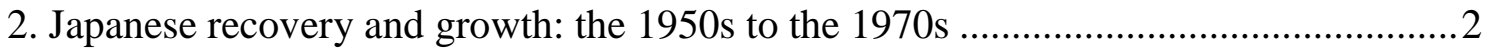

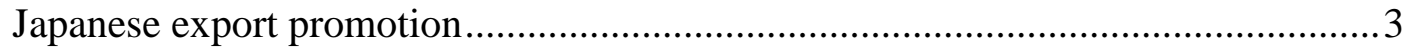

3. From aid recipient to industrial giant: South Korea from the 1950 s to the 1980 s ........ 7

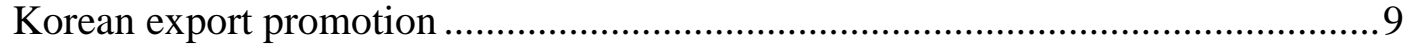

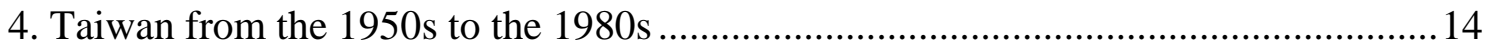

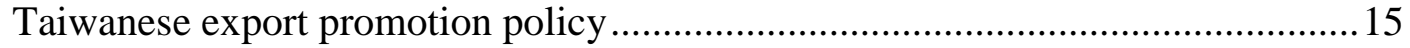

5. The Second Wave of Asian Growth: Indonesia, Malaysia, Thailand, and China .......19

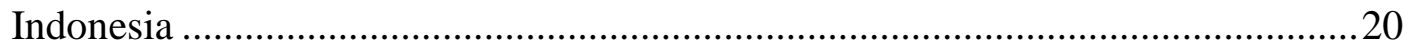

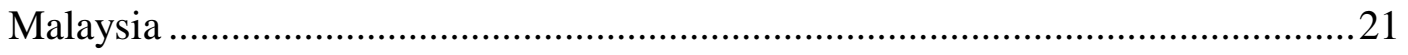

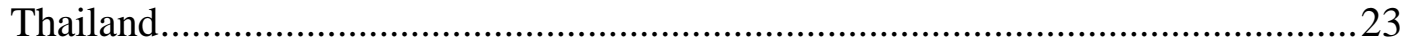

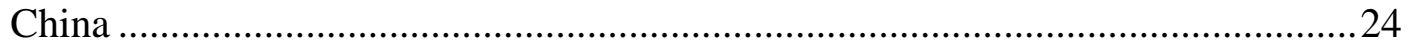

6. Lessons and conclusions regarding export promotion ...........................................27

7. What can Europe's transition economies learn? .......................................................29

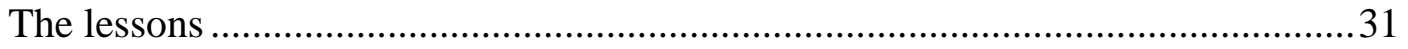

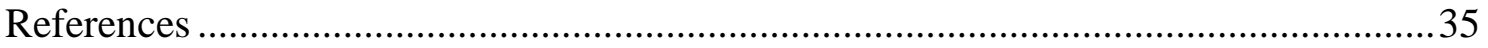




\section{Abstract}

This paper summarizes some East Asian experiences of export led growth and export promotion policies, and discusses possible lessons for today's European transition economies. It is argued that the East Asian developments identify a potentially important role for public support to infrastructure development and provision of various business development services (such as insurance and trade finance, information, and marketing skills) to small and medium sized exporters. These policies should be neutral across sectors rather than selective. The Asian experiences also point to the importance of maintaining competitive exchange rates, which, however, may be hard to achieve in those transition economies that aim to fulfill the Maastricht criteria regarding price and exchange rate stability. 


\title{
Foreword
}

\author{
by János Gács
}

This paper is one of the results of a broad, multi-year research project of the Economic Transition and Integration Project of IIASA entitled "Catching Up and EU Accession - Prospects for First and Second Wave Countries". The research was particularly encouraged by IIASA's Swedish and Hungarian national member organizations, while financial support was provided by the (then) Swedish national member organization, the Swedish Council for Planning and Coordination of Research (FRN). Preparations for the project started in 1999. In addition to other forms of communication two workshops, one in Budapest in January 2000, and one in Stockholm in May 2001, helped to elaborate the research agenda, coordinate collaborative work and discuss results. Publication of the studies prepared in the framework of this projects started in September 2001.

The main ideas of the research project can be summarized as follows.

The accession of the Central and East European countries (CEECs) to the EU is likely to lead to conflicts between these countries and the incumbent members unless there is a rapid narrowing of the gap in per capita incomes between them. The CEECs are much poorer and have proportionately much larger agricultural sectors than the average EU country, and their combined populations make up between one-fourth and one-third of that of the current EU. Due to these characteristics there is concern in EU member states about a mass migration from the East following accession, about social and environmental "dumping" from CEECs, and about an increased demand by the CEECs on the EU's Structural and Cohesion Funds, as well as on the funds provided under the Common Agricultural Policy.

These concerns, however, are counterbalanced to a large degree by a "catching up" predicted by both theory and experience: poorer countries, unless their development is impeded by institutional barriers, usually develop faster than richer ones, and there is a tendency toward convergence in levels of GDP per capita. In recent years, this catching up process seems to have started. In addition, trends in capital inflows and stock market developments suggest that the expected return on capital in the region is sufficiently high to support the buildup of stronger production capacities.

The research project on catching up studied the pattern according to which preparations for membership can trigger changes that will affect the growth process before and after membership. Special attention was paid to CEECs in different positions: those that started negotiations in 1998 and may reach membership first, and those that started negotiations in 2000. The effects on the sources of growth in both the pre-accession and post-accession periods were studied. 
The following specific topics were investigated by the contributors of the project: the relevance of the export led East Asian development experience for CEECs; the forces of convergence and divergence that worked in the less developed EU member states (Spain, Portugal, Ireland and Greece) following their accession; the mixed experience of East Germany in catching up in a growth theoretic perspective; the role of domestic savings and savings behavior in the catch-up process; the likely pattern of the so-called Balassa-Samuelson process (real appreciation associated with the expected rapid productivity growth) in the course of the convergence; evaluation of the possible effects of EU structural aid on the candidate countries' development based on the experience of the cohesion countries of the EU; financial convergence of the candidate countries to the EU and the growth process; the role of institutions in the process of transition and catching up; and the relationship between the growth process and human development (health, education, standard of living, including inequality) in the context of EU accession. 


\section{Acknowledgments}

I am grateful to David Dapice, Robert Glofcheski, János Gács, and members of the IIASA project team for useful comments on earlier drafts of this paper. 


\section{About the Author}

Ari Kokko is professor and Director of Research in the European Institute of Japanese Studies, Stockholm School of Economics and is also professor at the Department of Business Administration, Åbo Akademi University, Finland. In 20002001 he participated in the research project „Catching Up and EU Accession Prospects for First and Second Wave Countries" of the ETI project of IIASA. 


\title{
Export-Led Growth in East Asia: Lessons for Europe's Transition Economies
}

\author{
Ari Kokko
}

\section{Introduction}

With reasonably low inflation and positive GDP growth rates in most of Europe's transition economies since the late 1990s, the focus in the economic policy debate has gradually shifted from stabilization and recovery to questions concerning long term growth and convergence. The new key challenge is to establish a policy environment that will facilitate catching up: there is a growing consensus that the transition economies will not be able to benefit fully from European integration unless the development gap to the rest of Europe is reduced.

Some general guidelines for what is required in this process are provided by the long-term growth experiences of the richer EU countries. These include a central role for the private sector, free markets and prices for the efficient allocation of resources, appropriate incentives for entrepreneurship, and participation in the international economy, but also an important role for the public sector. Sustainable development requires a strong state to maintain competition and protect property rights, and to provide infrastructure, education, and social services in those cases where the market outcomes are not satisfactory. However, the Western economies have evolved relatively slowly over a long period of time, and their recent history does not provide many explicit insights about the requirements for rapid convergence of the kind attempted by the transition economies. The growth experiences of some East Asian economies, on the other hand, are likely to offer important lessons about catching up. For instance, Japan and the first-generation Tigers, such as Hong Kong, Singapore, South Korea, and Taiwan were able to raise their per capita incomes from a few hundred dollars in the 1950s to high OECD standards in the 1990s. More recently, countries like Indonesia, Malaysia, Thailand, and China have been able to sustain high growth rates for extended periods of time, managing to significantly narrow the development gap. Although some of the magic surrounding these achievements has worn off because of the financial crisis that erupted in 1997, it is still relevant to examine the region's growth experiences in light of the challenges facing today's European transition economies. In fact, against the backdrop of the Asian crisis, it is reasonable to expect that any lessons will be more balanced and realistic than they would have been only a few years ago, when the Asian Miracle appeared hard to understand without reference to abstract concepts such as Asian values.

Looking at the Asian economies that have recorded the most impressive economic performance during the past decades, it is impossible not to notice the connection 
between strong export orientation and periods of rapid growth and development. In most cases, high and sustained economic growth was preceded by shifts from traditional import substitution to more export oriented and outward looking policies, resulting in export growth rates reaching 20 percent per year (or more) over extended periods of time. The focus of this paper will therefore largely be on the policies underlying Asia's export success, although it we will also make some references to the more general policy regimes that facilitated the high growth and relatively stable macroeconomic development in the region up to $1997 .{ }^{1}$ The three cases that will be discussed in closest detail are Japan, South Korea, and Taiwan. These are all unquestionable success stories, and their starting points after the Second World War, as resource poor, densely populated, and largely agricultural economies, are in many respects similar to present conditions in many of Europe's transition economies. The analysis of these countries will primarily cover the period to the mid-1980s (in the case of Japan, to the 1970s) when the basis for the export success was established. Experiences from the second generation of newly industrialized economies (Indonesia, Malaysia, and Thailand) and China will be discussed more briefly. For these cases, the discussion will cover developments to the mid-1990s: the Asian crisis will not be discussed in detail, except when the pre-crisis policies clearly led to imbalances that subsequently contributed to the crisis itself. The next four sections summarize the country experiences, while the final section attempts to draw some lessons for growth and export promotion in Europe's transition economies.

\section{Japanese recovery and growth: the 1950 s to the 1970 s}

Japan emerged from the Second World War with a devastated economic base and a foreign occupation force -headed by General MacArthur, the Supreme Commander for Allied Powers (SCAP) - that set the course for the reconstruction and rehabilitation of the Japanese economy. Although the Allied policies during the first couple of years after the war focused on the extraction of war reparations and the breaking up of the large zaibatsu conglomerates that had run Japan's war industry, there were also more constructive and ambitious objectives. For instance, a new Japanese constitution was introduced establishing Western style parliamentary democracy, and the broad land reforms that were implemented in 1945-46 introduced an important element of economic democracy, redistributing wealth from landlords to tenants. This notwithstanding, Japanese economic recovery was not high on the agenda before the late 1940s: the primary aim of the SCAP, aside from the new democratic constitution, was to "punish the guilty" (Flath 2000: 83). However, economic development including the reconstruction of Japanese industry - emerged as a new major objective after the communist victory in China (see further Tsuru 1993). Japanese recovery became desirable because the US needed a strong ally in the Far East. Allied policies changed accordingly. For instance, although the Dodge plan of 1949 was primarily set up to achieve macroeconomic stability after the turbulence and high inflation of the immediate post-war period, it also set up some of the basic conditions for the subsequent recovery and export expansion. In particular, the Ministry of International

\footnotetext{
${ }^{1}$ For a broader discussion about the possibility to adopt Asian growth policies in the European transition economies, see Sachs and Warner (1996). Stiglitz (1996) also summarizes some of the lessons from the Asian miracle.
} 
Trade and Industry (MITI) was given the power to influence the country's industrial development: the Foreign Exchange and Foreign Trade Control Law of 1949 was one of MITI's main instruments for selective intervention in development of individual industries or even companies. Moreover, the exchange rate was fixed at 360 yen to the US dollar, which made Japanese goods relatively cheap in the world market and boosted the country's export potential. These policies, in combination with a well-trained labor force - which was essentially the country's only remaining competitive asset after WW II - and US procurements from Japanese industry during the Korean War (1950-53) facilitated the recovery of the Japanese economy. Yet, by the time the Allied occupation ended in April 1952, GDP per capita was still well below USD 200 in current prices, and it was believed that the country's economy would have to "depend on the Western industrialized economies for a long time before stabilizing at any level" (Das 1996:492).

This belief turned out to be incorrect. Over the following decades, Japan developed one of the world's most efficient, advanced, and wealthy economies. While the annual GDP growth rate of 8.6 percent in the period 1952-1955 may be attributed to post-war recovery and the Korean War boom, the 1956-1973 average growth rate of nearly 9 percent was clearly generated by a conscious effort to narrow the income and development gap to the West. During this period of extraordinary economic development, government policies were tailored to promote growth in the private sector, industry made a concerted effort to expand investment and absorb modern technology, and the population sacrificed current consumption in order to generate high savings that could finance the necessary investments. Savings and investment varied between one third and two-fifths of GDP. After 1973, growth has slowed sharply, although the average growth rate of 3.5 percent per year up to the early 1990s exceeded that of other industrialized economies. Since then, economic performance has been significantly weaker due to the inability of the Japanese political system to manage the fallout from the collapse of the real estate and stock market bubbles in the early 1990s.

Export success has been intimately connected with Japan's overall growth performance, and export growth averaged 17 percent per year until 1973. Exports did not only provide foreign currency to pay for the imports of raw materials, intermediates, and capital goods needed for industrial development, but it also allowed firms to grow large enough to benefit from economies of scale that could never have been achieved on the domestic market alone. Moreover, exporting exposed the large Japanese firms to tough international competition, and forced them to achieve higher efficiency than what the more concentrated and oligopolistic markets at home might have achieved in isolation.

\section{Japanese export promotion}

Although export success has been an important factor in the Japanese economic miracle, it is hard to point to many unique export promotion policies that could account for the success. The reason, as noted above, is that Japanese industrial policy at large has aimed to support the growth and competitiveness of Japanese industry, with the ultimate objective of catching up to the West. Firms and entire industries have therefore been encouraged to aim for export success even at very early stages of their development. In fact, the provision of infant industry protection, subsidized credit, beneficial tax treatment, and other measures to support emerging industries has often been conditional on satisfactory export performance. 
The main features of Japanese industrial policies have been related to competition policy and industrial rationalization. One of the immediate objectives of the Allied Powers, as noted earlier, was to do away with the institutions responsible for Japan's wartime expansionism. However, this objective was largely forgotten after the Communist victory in China, which made a strong Japan more desirable. In fact, Japan's post-war economic revival was largely managed by the same institutions that had controlled the country's economy during the war. At the center was the wartime Munitions Ministry, which had reverted to its pre-war title of Ministry of Commerce and Industry, and in 1949 adopted the name Ministry of International Trade and Industry (MITI). This Ministry was given wide-ranging authority and comprehensive responsibilities for industrial planning, financing, enforcing mergers, setting production quotas, rationing foreign exchange, and sourcing and allocating foreign technology to individual firms. The approach in the long-term planning of the economy was in some ways similar to that in socialist economies, with one important distinction: in Japan, competition was fierce even when MITI limited the number of players in specific sectors to avoid "excessive competition". Moreover, the government was not directly involved in manufacturing, which was the exclusive domain of private firms that were strongly motivated to increase their profits and prestige.

The main policy instruments until the 1960s were provided by the Foreign Exchange and Foreign Trade Control Law, introduced by the Allied Powers in 1949, and MITI-controlled investment funds, both in the government budget and in specialized credit institutions (such as the postal savings bank). These instruments gave MITI complete control over private industry through the allocation of credits and foreign exchange for imports. After the signing of the San Francisco peace treaty in 1952, the system was put to work to generate the highest possible growth rates, focusing on 44 "strategic" industries (including steel, shipbuilding, coal, and chemicals) which were expected to stimulate demand and production in other sectors. MITI provided the investment capital, foreign exchange, and technology needed to upgrade production. Nearly a third of the credit allocated to industry during the period 1952-1955 was subsidized, at several percentage points below market interest rates. Some machinery industries also benefited from significant tax reductions, corresponding to 6 percent of total corporate tax payments for the 1950-1955 period. Moreover, quantitative restrictions on imports and inward FDI were prevalent. The impact of these measures was positive, although the performance of promoted industries was not radically different from manufacturing in general. The strategic industries grew by a factor of 3.0 between 1950 and 1955, while all manufacturing grew by a factor of 2.9.

Until 1955, industry was essentially operating under MITI orders, during the period 1955-1960 control was managed through credit allocations, and from 1961 onwards, firms were allowed to prepare their own investment programs with "guidance" from MITI officials. Hence, the degree of official interventions was falling over time. The value of reduced interest rates and taxes between 1961 and 1973 was estimated at only 2 percent of investment for all manufacturing, 1.9 percent for steel, 4.9 percent for machinery, and 6 percent for power generation. ${ }^{2}$

\footnotetext{
${ }^{2}$ The heaviest subsidies went to shipbuilding and, in particular, shipping, where they amounted to nearly a third of investment. However, it should be noted that less than a fifth of subsidized
} 
Moreover, the quantitative import restrictions and exchange allocations were abolished and replaced by tariffs during the 1960s. Yet, the level of protection remained significant. By 1963, the average tariff for manufacturing was 32 percent, with higher rates of 37 percent for machinery industries and 62 percent for transportation equipment. It was also clear that MITI's "administrative guidance" continued to be law (see Buckley 1998). An example of MITI's power was given in 1965, when Sumitomo Metal Industries objected to a suggestion for an across-the-board reduction in crudesteel output. Sumitomo was quickly brought in line when MITI threatened to reduce its allocated quota of cooking coal.

The government also removed the parts of the Occupation structure that interfered with its plans for the economy. For instance, new laws were passed to allow MITI to create cartels as exceptions to the strict Anti-Monopoly Law that was modeled on US legislation. Major manufacturers and trading firms were under strong pressure to join a few leading business groups that had begun to develop soon after the war. Gradually, six large conglomerates emerged: Mitsui, Mitsubishi, Sumitomo, Dai-ichi Kangyo, Sanwa, and Fuji. The first three were largely re-creations of the pre-war zaibatsu, whereas the others were established under the leadership of the leading "city banks". Each of these keiretsu groups is built around a major commercial bank and a trading company, with arms covering all major industries and service activities, and they altogether account for between a quarter and a third of Japanese business activity (Doi 1989). The production networks of the keiretsu are held together through cross-holdings of stocks, president's clubs, interlocking directorships, and other institutionalized contacts, and the resources and activities of the different member companies are integrated and coordinated. Large and small firms within each group share capital, technical know-how, office buildings, and even staff. This structure makes it possible for the company group to conceive, design, manufacture, distribute, and sell new products using only its own or allied resources, which gives the keiretsu the strength to enter into the most demanding fields of business. The general trading companies have had a particularly important role in facilitating the Japanese export success.

The keiretsu structure also constitutes a major barrier of entry for new firms, foreign as well as domestic, who may be unable to tap into existing supply and distribution networks. However, although the number of contestants in the market has generally been low (and regulated by the authorities) there has usually been strong rivalry among several firms in every sector. This has guaranteed productive efficiency, and the system of "competitive oligopoly" was arguably a major factor in keeping the leading Japanese businesses internationally competitive.

In addition to competition policy and industry structure, MITI has also taken responsibility for technology imports. Although the initiative for the import of technology lay with the private sector, MITI intervened in three ways. First, by discouraging inward foreign direct investment, MITI probably made foreign firms more willing to license their technology without any direct management or ownership involvement. Second, MITI often designated one domestic firm to deal with a particular foreign supplier. This weakened the licenser's bargaining position, since he could not

credit went to industry during this period. Economic infrastructure and agriculture were the most favored sectors. 
take advantage of competition between Japanese firms to raise his price. Third, MITI often intervened directly in negotiations in order to reduce royalties or to alter other conditions in favor of the Japanese parties. Hence, it is estimated that Japan paid only about USD 10 billion between 1950 and 1980 to acquire all the foreign technology it needed.

Some important institutional innovations were also managed by MITI. In 1950, an Export Bank was established. This bank, later renamed the Export-Import Bank, used government funds to stimulate exports of capital goods, such as ships. In 1951, the Japan Development Bank was created to provide investment funds for industry. The resources of these two institutions were largely spent according to MITI preferences, on projects judged to be in the national interest. Another important innovation was the establishment of the Japan External Trade Organization, JETRO. During the late 1940s and early 1950s, Japan's increasing engagement in international trade was organized largely at the mercy of foreign buyers, since all the overseas commercial outposts for information gathering had been lost during the war. Not only had the main trading companies like Mitsui \& Co. and Mitsubishi Corporation lost their overseas branches and offices, but the zaibatsu dissolution program had also split them up into hundreds of small units. Hence, JETRO was set up in 1951 to establish the necessary overseas trade network, at the initiative of the private sector but with financing from the government. The purpose of the organization was "to conduct surveys on the general features and trends of Japan's major export markets as well as the specific conditions related to a particular product in a particular overseas market", "to disseminate the collected information to the domestic firms through JETRO's newsletters and its journals", and "to create demand for Japanese exports through participation in international trade fairs, dispatching trade-fair ships around the world, displaying Japanese export products at overseas exhibition centers and distributing trade-promoting publications" (Ozawa and Sato 1989: 18).

The main beneficiaries of JETRO's early activities were probably the small and medium-sized enterprises in textiles and light manufacturing, since the large keiretsu could soon rely on their own general trading companies, the sogoshosha (see Tsurmi 1980). However, JETRO has rarely competed with the general trading corporations and various industry-specific export trade associations that emerged in Japan during the 1950s and 1960s, but rather turned more and more to provide services in public-good type activities that benefit all of Japanese industry. In fact, the scope of operations of the organization and its role as a trade and investment promoter have been expanding and diversifying with the globalization of the Japanese economy, so that promotion of imports and inward investment has now become important tasks for JETRO.

Apart from the formal institutions discussed above, it is also common to point to some other unusual Japanese institutions as explanations of the country's long-term success, both in economic development in general, and exports in particular. The lifetime employment system, the seniority wage system, and the enterprise unions are often credited for the strength and stability of the largest Japanese firms. Because of these features, Japan benefits from greater labor commitment, loses fewer days to labor conflicts, innovates more easily, and manages a superior level of quality control. In addition, the Japanese economy differs from most others because of its high personal savings rates, the high status and competence of the bureaucracy, the weak position of shareholders versus company management, and other characteristics related to history, 
tradition, and culture. It is very likely that some of these characteristics have also had a positive impact on the tremendous economic success.

However, it is uncertain which of these features are relevant for countries trying to learn from the Japanese experience. For instance, Johnson (1982) argues that "Taken together as a system, [these features] constitute a formidable set of institutions for promoting economic growth... but taken separately, as they most commonly are, they do not make much sense at all." To phrase this caveat more generally, it is possible that the Japanese experience is too special to be copied easily by any one of today's emerging market economies. Unlike most other countries embarking on an ambitious development strategy, Japan had a well established industrial tradition and a well educated, highly skilled, and disciplined labor force. It is possible that these were the main determinants of Japan's subsequent success, rather than any specific policy measures implemented by the authorities. ${ }^{3}$ The large size of the Japanese economy (in combination with its strong export orientation) may also explain why the protectionist and interventionist policies implemented until the 1970s did not have the detrimental effects observed in most other countries that have attempted similar strategies. The domestic market had enough purchasing power to accommodate several firms operating at minimum efficient scale in many import substituting industries: both technical efficiency and competition could be retained behind the trade barriers. This notwithstanding, there is no doubt that export promotion played an important role for expanding Japanese market shares and encouraging efficient production. In particular, it is important to note the central role of the institutions set up to reduce information and transactions costs for small and medium sized exporters.

\section{From aid recipient to industrial giant: South Korea from the 1950s to the 1980s}

After the Second World War, the Korean peninsula was divided into two separate parts along the 38-degree line. When South Korea (the Republic of Korea) formally became independent in 1948, the new nation was severely handicapped by a lack of natural resources. The partition of the peninsula had left the South with the majority of the population, the minority of the land, and little industry, while the North controlled heavy industry, large mineral deposits, and almost all of the hydropower facilities. In addition, the country's initial development ambitions were badly hurt by the North Korean invasion in 1950 and the ensuing war.

A comprehensive import-substituting development strategy, largely financed by US aid, was initiated soon after the truce in 1953. Although the average annual GDP growth rate during the rest of the 1950s reached about 5 percent, Korea remained one of the poorest countries in the world. The dismal export performance during the import substituting phase provides one indication of the country's weak industrial

\footnotetext{
${ }^{3}$ In fact, Sakoh (1984) and Trezise (1984) argue that Japan's performance has less to do with government intervention than with market forces. Their argument is essentially that MITI and other authorities have been successful when their actions have been in line with developments in the market, but not when they have tried to interfere with market forces.
} 
competitiveness in the 1950s: the real value of the country's manufactured exports actually fell by about 80 percent between 1953 and 1959 (Suh 1996: 578). The limited export success also highlights the role of US aid to finance the necessary imports of technology, machinery, intermediates, and raw materials during this period.

However, in spite of the relatively slow economic development under import substitution, the Korean government instituted two policies that turned out to be of utmost importance for subsequent development. Firstly, the population pressure, worsened by substantial immigration from the North, necessitated a comprehensive land reform. The reform, initiated in 1949, limited the maximum size of household holdings to three hectares, and created a very egalitarian distribution of income and wealth among the majority of the population. In fact, nearly a quarter of total arable land was redistributed in this program. Secondly, education was identified as one of the highest development priorities immediately after independence, and significant public resources were invested in the sector.

The character of development strategy changed radically from the early 1960s. One reason was the substantial reduction of US grant aid (from 1963), which forced the country to increase its export revenues in order to pay for the necessary imports of fuel and capital goods. Another cause was found in the widespread political changes that followed the political unrest and a student revolution in 1960. A military coup in 1961 brought General Park Chung Hee to power, and the actions taken by the military regime over the next few years reshaped the political economy of the country in a more or less permanent manner. One of the first moves of the Park regime was to nationalize all financial institutions, in order to place all decisions regarding the allocation of credit in the hands of the government. At the same time, many prominent businessmen were imprisoned, accused of having accumulated "illicit" wealth. They were later released against promises to serve the nation by investing according to the state's development objectives. The incident left a large share of the business community morally obliged to adopt the state's development objectives (Chang 1993:151-2). Economic decisionmaking power was also centralized in a super-ministry, the Economic Planning Board, which assumed responsibility for the tasks normally divided between specialized planning, industry, and finance ministries. The sum of these and other actions was to create an exceptionally strong state that was in a position to command a radical change in the country's development strategy. The major performance requirement from the 1960s and onwards has been "export success".

Hence, although the Korean economy can be characterized as a private market economy, it is important to note that the state has had an important role in generating the country's impressive development since the early 1960s. The most important element of government intervention has probably been the establishment of a set of rules that impose strong export orientation. Detailed Five-Year Plans - the first one covering the period 1962-1966 - have defined the current development objectives, often stated in terms of export performance, and various regulations, incentives, and interventions have been used to realize the plans. The sectors targeted for exports had "priority in acquiring rationed (and often subsidized) credits and foreign exchange, state investment funds, preferential tax treatments (e.g. tax holidays, accelerated depreciation allowances) and other supportive measures, including import protection and entry restriction" (Chang 1993:141). In return for these benefits, industry was expected to prove its value for development by fulfilling ambitious productivity and export targets. 
Unlike most other countries that have opted for development strategies with equally comprehensive state intervention, Korea was highly successful for a long time. Table 1 below outlines some of the performance measures during the five Five-Year Plan (FYP) periods starting 1962. Apart from high aggregate growth rates, it should be noted that investment and savings as a share of GDP grew throughout the period in question. In 1966, savings reached 12 percent of GDP while investment amounted to 22 percent. Savings had grown to 24 percent of GDP by 1976, and further to 31 percent by 1986. The investment share of GDP stood at 25 percent in 1976 and 30 percent a decade later. It is also remarkable that average export growth was maintained at above 25 percent per year until the mid-1970s, and at double-digit rates thereafter. In absolute amounts, exports increased from USD 54 million in 1962 to USD 3.3 billion in 1973, USD 17 billion in 1980, and USD 60 billion in 1988. The export strategies implemented during these three decades fall into three distinct phases. During the first and second FYPs, there was an intense drive to increase exports of any sorts. The third and fourth FYPs (until 1979/80) were marked by a bias in favor of heavy industry. The period after 1980 has been characterized by increasing emphasis on high-tech exports.

In addition to describing some of the specific export promotion measures that have facilitated this impressive record, the following paragraphs will also point to some reasons why Korea succeeded when most other countries have failed to generate sustainable export and income growth with equally significant state intervention.

Table 1. Real growth rates of GNP, Investment, and Exports in the Five Year Plan (FYP) periods, 1962-1986 (percent)

\begin{tabular}{lllll}
\hline & Years & GNP & Investment & Exports \\
\hline $\mathbf{1}^{\text {st }}$ FYP & $1962-66$ & 7.8 & 23.2 & 26.2 \\
$\mathbf{2}^{\text {nd }}$ FYP & $1967-71$ & 9.6 & 18.5 & 30.3 \\
$\mathbf{3}^{\text {rd }}$ FYP & $1972-76$ & 9.6 & 12.7 & 27.6 \\
$\mathbf{4}^{\text {th }}$ FYP & $1977-81$ & 5.9 & 8.0 & 12.3 \\
$\mathbf{5}^{\text {th }}$ FYP & $1982-86$ & 5.7 & 9.4 & 11.8 \\
\hline
\end{tabular}

Source: Suh (1996), Table 24.1.

\section{Korean export promotion}

In the field of trade policy, tariffs and other trade barriers provided significant protection for Korea's domestic industry until the 1980s, and import substitution played an important role in most consumer goods and capital goods industries (Chang 1993:132-135). Yet, export promotion became an integral part of the development strategy already from the 1960 s, for several reasons. Industrialization required massive imports of foreign technology and raw materials, and growing export revenues were needed to cover the rapidly growing import bill, particularly after the sharp reductions of US aid in 1963. Another reason was that industrialization required more investment resources than what the domestic market could generate. Unlike in Japan, domestic savings were not sufficient to finance domestic investment, and inflows of foreign capital were needed to cover the savings gap. Consequently, export revenues were needed to service the foreign loans. In addition, many of the designated priority sectors 
were characterized by significant economies of scale, and the state systematically instructed industry to build their plants sufficiently large to reach efficient production scale. Hence, exports were also necessary to avoid losses from low capacity utilization in priority industries (Chang 1993:140).

The Korean export promotion policies have included various kinds of subsidies, preferential prices, and tax and tariff exemptions, although preferential access to credits has probably been the most important individual measure. The major policy reforms in this field were instituted in the 1964-67 period. At the beginning of the period, the Korean Won was devalued by almost 100 percent against the US dollar, with obvious benefits for exporters. A major target of macroeconomic policies during the following two decades was to keep the real exchange rate roughly stable, to keep exporting profitable and minimize excess demand for imports. This objective was achieved through periodic nominal devaluations and strict aggregate demand management that never allowed inflation to get out of hand. Imports of capital goods, equipment and intermediate inputs were exempted from tariffs. Exporters were given credit at preferential interest rates, as well as reduced rates for electricity and transportation services. Accelerated depreciation schemes and other tax benefits were also introduced. Moreover, the full set of export incentives was made available also for producers supplying intermediate inputs to the exporters, providing an additional stimulus to the development of the country's domestic production capability.

Few of the individual export incentives differ much from those that can be found in other countries, but many observers have noted that the aggregate weight of these policies was high enough to provide roughly equal incentives to production for exports and domestic sales, in spite of significant tariff and non-tariff barriers. This has been proposed as one of the reasons why the efficiency losses have been relatively small, in spite of the fact that many import restrictions barriers remained until the 1980s (World Bank 1993). Another important reason is that the Korean industrial and trade policy regime has provided explicit links between domestic protection and exports. Westphal (1978: 373) reports that access to protected domestic markets was dependent on satisfactory export performance, so that "newly established import-substituting industries have been generally encouraged to begin exporting almost at once". Consequently, many essentially import-substituting firms learned to adjust to competition and market discipline in their export markets at the same time as they enjoyed protection at home.

Whereas most of the specific microeconomic policies to promote Korean exports are commonly found in other countries, Korea also followed the less common Japanese example by establishing several new institutions to encourage the outward orientation of the economy. The Korea Trade Promotion Corporation (KOTRA) was established in 1962 with government support to do market research and to promote exports, in particular for small and medium sized enterprises. The Korean Institute for Science and Technology supported the importation and adoption of foreign technologies. The Korea Traders' Association institutionalized the contacts between business and government, and their Special Fund for Export Promotion, established in 1969, was well financed by mandatory contributions of 1 percent on most imports. Korean embassies abroad were required to participate actively in trade missions and other forms of trade promotion, and the government established detailed export targets for individual commodities, markets, and exporters. There were daily printouts of exports by company, and monthly 
meetings chaired by President Park, attended by business executives and top bureaucrats, to avoid administrative obstacles and other bottlenecks. The highest export achievements were formally rewarded with the national medal of honor, Presidential commendations, and various more material benefits, such as relaxation of tax surveillance. One purpose of the export targeting system was to provide the government with information on export performance: this was needed to monitor the efficiency of export incentives and to adapt policies to the continuously changing international environment. Another purpose was to signal the importance of exports in the development strategy. The incentives were well advertised and the Korean business community had no doubts that export success would be rewarded (Westphal 1978: 376).

Furthermore, in the early 1970s, the first export processing zones (EPZs) were established in Masan (1970) and Iri (1973). Up to that time, the Korean government had chosen not to encourage inward foreign direct investment, and FDI had not exceeded 3 percent of total investment during the 1960s. However, the new EPZs were especially designed to suit foreign firms in selected industries, such as electronics and textiles and clothing. By providing automatic access to all export incentives, the EPZs were able to attract a notable number of foreign multinational corporations, and by 1978, foreign firms had grown to account for three quarters of the Korean electronics exports and around 10 percent of textile and clothing exports. However, various restrictions limited the possibilities of foreign firms to establish affiliates outside the export processing zones, and the aggregate share of foreign-owned enterprises remained small until the financial crisis in the late 1990s led to comprehensive liberalization and significant inflows of new FDI.

A result of the strong export drive initiated in the early 1960s was that Korea emerged as a major exporter of labor-intensive products, such as textiles and garments, silk, plywood, and fish. However, the structure of exports was changing rapidly. Individual industries proved remarkably efficient in graduating from import substitution into exporting, so that the Korean export structure was in a steady transition towards activities with higher value added. By the 1980s, exports were dominated by new products, like color TV sets, computers, and cars. In most other countries where significant import restrictions have been in place, this transition has been slow because attempts to withdraw support from protected industries have typically met with strong resistance from the interest groups that risk losing their privileges. What differentiates the Korean experience from many others is that the Korean state was stricter in enforcing productive and allocative efficiency and upholding hard budget constraints until at least the 1980s. Hence, it was clear to most actors that import protection, subsidies, and other rents are temporary supports, that all firms are eventually expected to manage in international competition, and that the government is able and willing to withdraw support from firms and industries that fail to reach their performance targets. Restrictions on entry and expansion limited excessive investment in protected industries, and the sanctions for inefficient firms - and industries - were generally harsh. Chang (1993) refers to several instances where the Korean government forced firms into mergers, sales, or liquidation because of inefficiency or "excessive competition", causing low capacity utilization or low profitability, while Thomas et al (1991:131) note that no advance assurances of emergency assistance were generally available, and that the bankruptcy rate among exporters was relatively high. 
The Korean success in disciplining industry may be partly explained by the tough measures undertaken by the military regime during the early 1960s to expose domestic industry to international competition, but another reason may be the fact that the trade related interventions were concentrated to a limited number of very large private firms, the chaebol. These are large diversified business conglomerates that typically operate in several import substituting as well as export oriented areas, generally in tough competition with other chaebol. The government's ability to link a firm's performance in one industry to promises of support (or threats of withdrawal of support) in other industries has arguably been important.

However, there are several episodes demonstrating that not even Korea has been immune to the various problems related to selective intervention. One is related to the Heavy and Chemical Industries Drive of the 1970s. Although the Korean trade regime provided strong support to exports from the early 1960s, it was roughly neutral with respect to the composition of exports until the early 1970s (World Bank 1993: 128). This meant that almost all the various export promotion incentives were automatically available to all exporters without discrimination. The neutrality contributed to efficiency, since potential exporters were automatically directed to areas where Korea possessed some inherent comparative advantages. In 1973, there was a shift away from neutral export incentives to a strong bias in favor of heavy and chemical industries. One of the reasons for the promotion of heavy industry was a fear that US military assistance would diminish. This necessitated the growth of strategic defense industries in preparation for a possible North Korean attack. Three sectors - steel, petrochemicals, and nonferrous metals - were singled out to enhance self-sufficiency in industrial raw materials. Concurrently, the shipbuilding, electronics, and machinery industries were selected to become the country's future technology-intensive export base. As earlier, these priority industries were supported with preferential access to cheap credits, tax credits, accelerated depreciation allowances, tax holidays, and import protection. The government also promoted heavy investments in infrastructure and industrial parks. Since most of these industries are characterized by economies of scale, an export orientation was necessary from the very beginning. With only 34 million inhabitants, the domestic market was too small to allow reasonable capacity utilization rates.

Although this endeavor to create a national heavy-industry sector was more successful than similar projects in other developing countries - largely because international competitiveness was the explicit performance measure from the very beginning - it can still be argued that it serves as a caution regarding the dangers inherent in attempts to tailor industrial development. The direct export share of the promoted industries grew, but only from 25 percent in 1973 to 28 percent a decade later. The opportunity costs of the bias in favor of heavy industry were significant, since the preferences automatically translated into a bias against other sectors. Soon enough, serious supply bottlenecks started emerging in light manufacturing industries, generating inflationary pressures and weakening the competitiveness of traditional exports, e.g. textiles. Large debts had been incurred to finance the necessary capitalintensive investments (at the expense of investment in other sectors), but low capacity utilization, partly brought about by the second oil shock in the late 1970s, forced many of the promoted firms to default on their loans. The slowdown in the growth rates of GNP, investment, and exports were partly due to these problems. There were also serious repercussions on the financial system and the overhang of bad debt from this 
period burdened the commercial banks well into the 1990s. Moreover, the distortions caused by lobbying and rent-seeking were probably significant, but it was not until the late 1990s that political scandals and the financial crisis in Korea revealed some of these consequences of the earlier selective interventions. One important conclusion is that there is reason to be extremely cautious regarding any government's possibilities to conduct selective intervention without inducing costly rent-seeking and corruption.

The fact that Korea was not able to copy Japan's success in government-led development of heavy industry, in spite of an environment where industrial structure, institutions, political control, and other characteristics were comparable to those in Japan, may illustrate the relation between the success of MITI-style targeting and market size. Korea was small relative to Japan, and problems with competition, capacity utilization, and efficiency emerged much sooner than in Japan. Thus, a more marketoriented approach came into force from the early 1980s, including not only cuts in the subsidies to strategic industries but also a gradual liberalization of the country's trade regime. The reduction of the bias in favor of heavy industry led to improved economic performance from the mid-1980s, with significantly higher GDP growth rates and export growth rates than during the late 1970s.

Another problem was that the heavy and chemical industries drive contributed to the further concentration of economic power in the hands of the chaebol, since the government had encouraged only the largest business groups to participate in the promoted projects. The clashes between government and the increasingly powerful chaebol have been a recurrent theme in the gradually less authoritarian political systems that emerged in South Korea after the assassination of president Park in late 1979.

Park's successor as president, Chun Doo Hawn, also seized power in a military coup. Following Park's example, Chun's government tried to control the business sector by threatening to prosecute business leaders on charges of "illicit wealth accumulation" unless they cooperated with his new economic policies. The chaebols formally pledged their loyalty to the new government, but the state-business relationship during the following decades turned out to develop very differently from Park's cooperative developmental state model of the 1960s and 1970s (Moon 1994: 147). One reason was that the chaebol very much more influential and powerful than two decades earlier. Another reason was that Chun's economic policies - in particular, the ambition to reduce business concentration by forcing the largest corporations to sell off assets were clearly contradictory to the interests of big business. Other rules were established to promote small and medium-sized firms. There were two motives for these policies: aside from the neo-liberal economic philosophy of the new leadership, it was necessary to distance the new government from the problems caused by the previous governmentchaebol coalition (Moon 1994: 146-152). Paradoxically, the result was to strengthen the position of big business. The efforts to reduce the concentration of ownership had little effect, and the chaebol were instead the first to seize the investment opportunities when new sectors were liberalized. The liberalization of the financial sector was particularly important, since it allowed the large industrial conglomerates to become more independent from state-controlled credits.

The next president, Roh Tae Wooh, democratically elected in late 1987, initially followed Chun's anti-chaebol policies which, however, changed a few years later, after heavy pressure from industry. A conservative coalition, the Democratic Liberal Party, 
was established in 1990, and government policies shifted to favor big business. The Korean won was depreciated to boost exports and most of the various nominal restrictions on chaebol expansion that had been introduced during the preceding decades were lifted. The result was a very significant increase in investment, and a temporary boom in growth. However, new problems had emerged by the mid-1990s. In addition to challenges from rising labor costs, Korea was struggling with the weakness of the banking sector, the financial problems of some chaebol that had incurred too much debt, and several corruption scandals that surfaced as a result of the increasing political transparency and democracy. These were all, to some degree, reflections and results of the interventions and industrial policies of the past decades. Moreover, the liberalization of the financial market, both domestically and internationally, had increased the supply of investment capital and contributed, together with state supported efforts to make inroads into some new "strategic" high-tech industries, to the rapidly increasing indebtedness of the corporate sector. The risks related to offensive development policies with emphasis on selected strategic industries were, once again, demonstrated during the turbulence following the Asian crisis. With the 30 largest chaebol posting an average debt-equity ratio in excess of 400 percent in early 1997, it was hardly surprising that a financial crisis could not be avoided (The Economist, March 7 1998: 6-7).

\section{Taiwan from the 1950 s to the 1980 s}

It can be argued that the conditions for economic development in Taiwan in the early 1950s were unusually beneficial, in particular in comparison with the concurrent developments in Japan and Korea. The new nation had inherited a relatively advanced economic infrastructure from Japanese colonialism; immigration from mainland China had created an ample supply of skilled and entrepreneurial labor; land reforms, similar to those undertaken in Japan and Korea, had been instituted; and inflows of aid from the US, comprising more than 30 percent of domestic investment each year until 1960, provided badly needed financial resources for development.

Yet, it would be wrong to ascribe the remarkable economic development of Taiwan during the past four decades to these historical circumstances. Instead, there is reason to emphasize the role of sound government policies in creating an environment where the private sector has been able to generate a high and steady rate of economic growth. Beginning with an early land reform that created a remarkably equitable distribution of income and wealth, the Taiwanese government has proceeded with policies that have facilitated the accumulation of human and physical capital, upheld a stable macroeconomic environment, and provided considerable support to domestic investments, industrial development, and exports. Some quantitative data reflecting the country's successful development are summarized in Table 2. 
Table 2. Macroeconomic Indicators for Taiwan 1952-1986

\begin{tabular}{|c|c|c|c|c|}
\hline Item & 1952-1961 & 1961-1971 & 1971-1981 & 1981-1986 \\
\hline Average GNP growth rate* & 7.5 & 10.2 & 8.9 & 7.6 \\
\hline Average inflation rate & 8.8 & 3.3 & 11.6 & 3.5 \\
\hline $\begin{array}{l}\text { Gross domestic investment } \\
\text { (percent of GNP) }\end{array}$ & & 22.4 & 30.7 & 22.2 \\
\hline $\begin{array}{l}\text { Gross national savings } \\
\text { (percent of GNP) }\end{array}$ & & 21.9 & 32.1 & 33.1 \\
\hline Export share (percent of GNP) & 8.8 & 18.5 & 42.4 & 50.3 \\
\hline Average export growth rate* & 8.5 & 23.5 & 13.8 & 13.1 \\
\hline Import share (percent of GNP) & 14.3 & 21.1 & 40.5 & 38.2 \\
\hline Average import growth rate* & 5.4 & 17.7 & 11.9 & 6.6 \\
\hline $\begin{array}{l}\text { Trade balance } \\
\text { (percent of GNP) }\end{array}$ & -5.5 & -2.6 & 1.9 & 12.1 \\
\hline
\end{tabular}

Note: * Calculated from data in constant 1981 prices.

Source: Kuo (1988), Tables 1 and 3.

The achievements during the 1960s, when Taiwan turned from traditional import substitution to a strongly export oriented development strategy, are particularly notable. The shift in strategy boosted exports, stimulated economic growth, contributed to a reduction of the inflation rate, and helped balance the country's external accounts. Like in Korea, the 1970s were marked by an attempt to target heavy, investment intensive industry, with only limited success. From the early 1980s, the focus shifted to high-tech industry, again in parallel with developments in Korea. However, Taiwanese economic development during the past decade has surpassed that of Korea, largely because of significant differences in the character of growth. While Korea's high-tech drive was centered on heavy capital investments in a limited number of large firms, Taiwan achieved its high-tech breakthrough through thousands of small and medium sized firms with significantly lower capital investment, lower indebtedness, and a more diversified industry structure.

\section{Taiwanese export promotion policy}

Taiwanese trade policy was largely characterized by import substitution until the late 1950s. With the objective of developing an industrial base for economic selfsufficiency, the government protected local producers of consumer goods, and invested heavily in infrastructure to support domestic industrialization. Policies included the usual import controls, tariffs, and multiple exchange rates, and the domestic currency was overvalued to facilitate the necessary imports of technology and capital goods. Moreover, state-owned enterprises held a dominant position in the manufacturing sector, especially in heavy industry. Import substitution was successful in the sense that industrial production more than doubled during the 1950s, with particularly rapid growth in labor intensive industries like textiles, apparel, wood and leather products, and bicycles. However, the limits to growth based on import substitution began to be 
noticed already in the mid-1950s. As the small domestic market gradually became saturated, the GDP growth rate declined from a high of 9 percent in the early part of the decade to about 6.5 percent in the mid-1950s. The financial costs of import substitution were also significant. In addition to the government budget deficits caused by the heavy public investment expenditures, the policies contributed to a growing trade deficit: the trade regime encouraged imports of technology, capital goods, and intermediate goods, but discouraged exports. These imbalances appeared sustainable during most of the 1950s, but only because the deficits could be financed by large inflows of US aid.

The US announcement that aid flows would be terminated by the mid-1960s, at the latest, forced the government to rethink its development policy. Without access to US aid, it would be necessary to find other sources of badly needed foreign exchange, and so the development strategy shifted to emphasize outward orientation, with export promotion emerging as a new policy objective. Consequently, starting already in 1958, the Taiwanese government introduced a series of policies to support exports and to promote inflows of foreign direct investment. The multiple exchange rates were gradually transformed into a devalued unitary rate, which translated into an effective devaluation of about 60 percent benefiting exporters. Tariffs and other import controls on capital goods and intermediates used by exporters were removed. A broad package of fiscal and institutional incentives - including cheap credits for exporters, income tax exemptions, and cheap export insurance - was put in place to further promote exports. The China External Trade Association, CETRA, was established to provide international marketing services, particularly for small and medium sized firms that would not have been able to afford such activities on their own. Foreign direct investment was also promoted with a powerful incentive scheme. Apart from a duty and tax-free trade regime, foreign investors were granted a five-year corporate income tax holiday and a subsequent maximum tax rate of 25 percent. During the 1960s, the government established several EPZs, bonded factories, and bonded warehouses. The investors in these zones enjoyed all the incentives and privileges granted to exporters in general, but without the red tape that was otherwise necessary. Concurrently, a gradual reduction of the effective protection of the domestic market was commenced.

Unlike Korea in the 1960s, Taiwan targeted specific industries already from an early stage. The promoted industries during the period up to about 1973 included plastics, synthetic fibers, apparel, electronic components, consumer electronics, home appliances, and watches and clocks. One important point to note about the choice of industries to be promoted is that these were selected on the basis of Taiwan's comparative advantages in cheap labor and the existing technological capabilities, in contrasts to the Korean heavy industry drive of the 1970s, which was not firmly based on existing comparative advantages. ${ }^{5}$ Partly for that reason, the policies proved extremely successful, and Taiwan's exports grew at an average annual rate of 28 percent between 1963 and 1972, from a mere USD 123 million to nearly USD 3 billion (World Bank 1993:132).

It is also notable that the export boom was led by private firms, in particular small and medium-sized enterprises. In the mid-1980s, the private sector consisted of 57,000

\footnotetext{
${ }^{5}$ The World Bank (1993:132) reports that the Taiwanese government hired the Stanford Research Institute to identify the industries that would be most suitable for export promotion.
} 
enterprises. On average, each of these firms employed only 40 people. Yet, the manufacturing sector was strongly dominated by large state-owned enterprises at the beginning of the export oriented period. The role of the state owned enterprises (SOEs) was not to export directly, but rather to exploit economies of scale in the production of inputs - plastics and fibers - for the private export sector. There was little privatization of state enterprises, and the demand from the growing export sector allowed the SOEs to expand at a reasonable pace throughout the 1960s. State manufacturing output doubled between 1964 and 1972. However, private manufacturing output virtually exploded during the same period, with production growing 11 times between 1960 and 1972. Figure 1 illustrates the distribution of manufacturing value added between private and public enterprises in Taiwan since 1952, and highlights the increasing dominance of the private sector. By 1972, about 85 percent of industrial employment and value added was accounted for by private firms. The growth of private industry was driven by a 50fold increase in manufacturing exports over the 12-year period. While agricultural products had accounted for 67 percent of exports in 1960, manufacturing had taken over with 83 percent of exports in 1972.

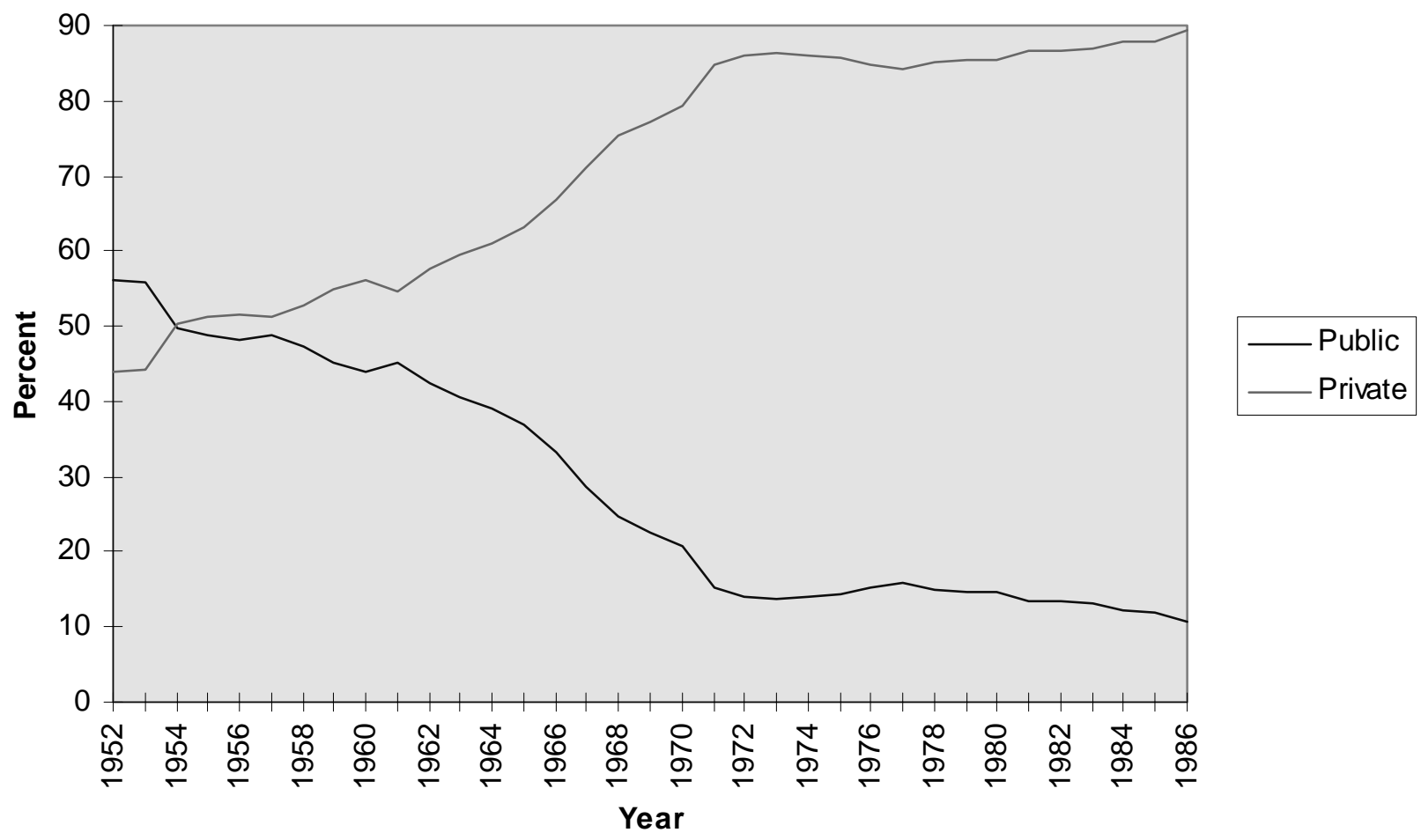

Figure 1 Distribution of Taiwanese Manufacturing Production (Value Added) by Ownership 1952-1986 (percent)

Source: Republic of China (1990), Table 5.4. 
Another significant characteristic of Taiwan's export-led development during this period was the great importance of foreign direct investment. Altogether, FDI inflows amounted to about 6 percent of gross capital formation during the 1960s, with a peak of 11 percent in 1971. The main contribution of these foreign investments was not so much the inflow of capital as the transfer and dissemination of knowledge and of skills, both in production technology and areas like marketing and distribution. This resulted in remarkably rapid industrial diversification and quality improvements - which are often prerequisites for successful export performance - during the early stages of Taiwan's export-led development process. The bulk of FDI was directed to export industries, in particular electronic and electrical appliances, and foreign firms accounted for 80 percent of Taiwan's exports of these products by the mid-1970s. This share has subsequently fallen, as local firms have grown into exporting in the same areas.

As a result of the successful promotion of labor intensive exports, the pool of surplus labor had been virtually exhausted by the early 1970s. The resulting scarcity of unskilled labor put pressure on domestic wages, and the emergence of new low-wage producers abroad began to challenge the Taiwanese export success. Serious bottlenecks also appeared in the transport, electricity, and communications networks. The first oil crisis added to the problems, and real GDP growth collapsed to only 1.2 percent in 1974. Exports declined by about 7 percent in real terms the same year. At that time, the government had already realized that a shift in the development strategy was necessary, and that future growth should be directed towards more capital and skill intensive industries. Hence, beginning in 1973, the Taiwanese government had embarked on a strategy to consolidate industrial development. The new plans focused on the development of capital intensive, heavy, and petrochemical industries to increase economic independence. In addition, a massive public investment program, amounting to some USD 8 billion, was put in place to remove the bottlenecks and revitalize the economy. The program included investments in highways, railroads, airports, and construction of nuclear power plants.

The attempt to establish a heavy industrial base was not a total success. While selective support for steel and petrochemicals appeared to be successful, there were clear failures in autos and shipbuilding. The costs of selective intervention in favor of heavy industry were probably not as large as in Korea during the same period, because the discrimination of other sectors was less pronounced. Although most small and medium sized enterprises did not qualify for cheap subsidized capital, they had better access to informal credit than what was the case for non-promoted firms and industries in Korea during the same period. Yet, the impressive growth rates of the 1960s and early 1970s fell to below 7 percent in the late 1970s, inflation rose, and Taiwanese exporters continued to suffer from the pressure of newly emerging low-wage competitors in the region and elsewhere. A new development strategy was therefore formulated in the early 1980s. The Taiwanese government decided to focus on hightechnology industries, such as information, biotechnology, machinery and precision instruments, and environmental technology industries (World Bank 1993:133). This shift required a broad and coordinated effort involving industrial, financial, scientific, technological, and human resource policies. Tax laws were revised to encourage commercial R\&D and upgrading of production technologies. New firms were supported with access to venture capital. Universities received additional resources to strengthen programs focusing on science, mathematics, engineering, and computer science, and 
programs to encourage qualified overseas Chinese to return to Taiwan were introduced. Concurrently, the speed of economic liberalization was accelerated to promote the further globalization of Taiwanese business.

In contrast to the heavy industry scheme, the focus on high-tech industry proved relatively successful. Growth rates recovered to above 9 percent in the late 1980s, the current account exhibited large surpluses throughout the 1980s, and Taiwan has become a major foreign investor and creditor. The progress during the 1980s was achieved with remarkable investment efficiency. A comparison with Korea is interesting. Although Taiwan's population was less than half the size of Korea's, and although the ratio of investment to GDP was a third lower than Korea's during the 1980s, exports and per capita incomes in 1990 were higher than in Korea. It is likely that these differences resulted from the stronger state intervention and larger subsidies to capital in Korea during the 1960s and 1970s. Korean industry has until recently been dominated by large chaebol operating in capital intensive sectors, often with access to subsidized credit, whereas Taiwanese industry is dominated by small and medium sized firms for whom capital has always been a scarce asset. The difference between these two strategies was forcefully demonstrated when the financial crisis hit the region in 1997-98. Whereas Taiwan's low level of indebtedness - both at the national and corporate levels - allowed it to manage the crisis without serious disturbances to the real side of the economy, Korea faced more severe troubles. The debt-equity ratio among Korea's largest firms averaged over 400 percent, with much of it of short maturity, and the reduced capital inflows following the crisis drove several of the leading chaebol to bankruptcy. The Korean economy is still struggling to manage the impact of the crisis.

\section{The Second Wave of Asian Growth: Indonesia, Malaysia, Thailand, and China}

At a general level, it can be argued that the trade and industrial policies of the economies making up the second wave of Asian growth - Indonesia, Malaysia, Thailand, and China - have developed in a manner similar to that in Japan, Korea, and Taiwan. After an initial period of import substitution (or, in the case of China, central planning) all four countries have gradually turned to more open and export oriented policies. The policy shift has led to significant increases in exports and imports, as well as higher GDP growth rates. The experiences of these countries are relevant for the European transition economies for several reasons. First, it is sometimes argued that the initial export success of Japan, Korea, and Taiwan in the 1950s and 1960s was mainly due to the unusually favorable world trade environment, with fixed exchange rates, few non-tariff barriers, and continuous global trade liberalization. The implication of this argument is that other countries are unlikely to succeed with similar export oriented strategies, because of a supposed increase in protectionism since the 1950s and 1960s. However, the countries discussed in this section have demonstrated the fallacy of this argument by entering successfully into the world export markets in the more complex international environment of the 1980s and 1990s. It is likely that the prospects for new exporters are at least as good now as during the 1980s, given the progress of GATT and WTO during the past years. Moreover, in spite of selective restrictions and exclusions, it is clear that the market access guarantees included in the Europe Agreements are more liberal than those available to the Asian economies during the past decades. 
Second, the Asian crisis has highlighted some of the weaknesses in the development policies of countries like Indonesia, Malaysia, and Thailand. Export promotion has not been as comprehensive as in Japan, Korea, and Taiwan - in particular, exchange rate policies have been used for macroeconomic stabilization rather than export competitiveness - export success and international competitiveness have rarely been required in return for protection, and governments have typically been more vulnerable to pressure from various interest groups. Nevertheless, it is notable that some of the lessons from the East Asian economic miracle seem to hold in Southeast Asia as well. Economic performance has been strongest during periods of prudent macroeconomic management, realistic exchange rates, and outward oriented trade policies.

Third, the Chinese experience shows that sustainable export booms can be achieved even in transition economies. China's transition and economic development during the past decade has been more predictable than that in East and Central Europe, where many of the institutions from the command economy collapsed in connection with the political transition. However, there has also been a larger degree of political risk in China: while the economy has become increasingly market oriented, China remains an authoritarian one-party communist state, with a significant degree of political risk for domestic entrepreneurs as well as foreign investors.

\section{Indonesia}

In Indonesia, trade policies have swung from protectionism to openness, partly as a result of the country's wealth of natural resources. From independence in 1948 to 1966, Indonesia followed a traditional import substituting development strategy with heavy state intervention. The combination of severe trade restrictions and general economic mismanagement had a detrimental impact on economic growth and welfare. The trade restrictions contributed to the emergence of powerful interest groups among traders and domestic industrialists, and the protected domestic industry was characterized by low efficiency and productivity. It is estimated that real per capita income declined by 15 percent between 1958 and 1965, inflation reached 1,000 percent in 1965, and the external accounts were in severe disorder (World Bank 1993:136). The resulting social unrest - culminating in an attempted communist takeover followed by a military coup and the massacre of more than half a million suspected communist supporters (mainly Chinese) - set the stage for a change in leadership.

The new authoritarian government under President Suharto restored macroeconomic stability, devalued the currency, and introduced significant reforms to support private investment. International capital movements were liberalized, and the trade regime was simplified and liberalized, although formal tariffs remained relatively high. The macroeconomic policy package, designed by a group of Western-educated economists known as the "Berkley mafia", proved highly successful. As a result of the reforms, the economy grew by about 50 percent between 1967 and 1972. Export growth also picked up, averaging 25 percent per year during this period. Foreign financial and political support, motivated by the country's resistance to communism, was important to support the domestic reform measures, as were inflows of FDI, initially focusing on oil an gas but later on diversifying to other areas of manufacturing. 
The increase in the price of oil and other primary commodities in the 1970s was a further stimulus to Indonesian economic growth. The surge in government revenue from oil exports allowed the state to take on a more active economic role, and several ambitious development programs were established. Significant progress was made in poverty reduction, health, education, and improvement of social conditions during the late 1970s (Hill 1996:191ff). Oil money was also used to finance substantial investment in infrastructure and heavy industry, and economic growth averaged 7.5 percent between 1973 and 1981.

However, the oil boom also sowed the seeds of future problems. Government investment in resource and capital intensive industry generate growth, but at the cost of inefficiency and distortions. As the role of the state and some favored groups of private industrialists grew stronger, regulations and restrictions on other private investment increased. Moreover, the large exports of oil led to an appreciation of the exchange rate, which reduced the competitiveness of non-oil exports and led to calls for protection from domestic interest groups. By the mid-1980s, it was clear that the trade regime was again favoring import substitution relative to exports. The growth rate fell to 4 percent during the period 1981-1985. The decline in oil and primary commodity prices in the mid-1980s highlighted the problems by causing a serious deficit in the current account.

The response to these imbalances was a new round of reforms, initiated in 1985. This time, the emphasis was on trade liberalization and export promotion. The currency was devalued, trade restrictions were simplified and lowered, and investment restrictions were reduced. The response to the more market oriented signals was again a rapid increase in investment and exports. Non-oil exports grew from USD 10.9 billion in 1985 to USD 39 billion in 1995. The share of manufactures in non-oil exports increased from 10 percent to 60 percent. FDI inflows accelerated. The GDP growth rate averaged over 8 percent during the same period.

Although Indonesia's economic performance appeared quite healthy during this period, some disturbing imbalances were noted already before the Asian crisis. The reliance on state-led industrialization and the special privileges for those in favored circles created strong interest groups and a political economy where further liberalization and deregulation appeared difficult (Hill 1996:93ff). The market-led export growth was also threatened by continuing state intervention and targeting of "strategic" industries. The Ministry of Research and Technology promoted the view that active state participation in industries like aircraft, steel, shipbuilding, ammunitions, and electronics was necessary for Indonesia to take a leap into modern technology. Although the financial accounts of SOEs in these sectors were not well published, it was clear that they absorbed enormous amounts of investment capital every year, and the return on this capital was very low, in spite of large subsidies and protection. In addition, the private sector was encouraged to borrow heavily to create competitiveness in these strategic industries. Indonesia's heavy foreign debt, corresponding to 57 percent of GDP and 200 percent of annual export revenue in 1997, was largely a consequence of these capital intensive projects.

\section{Malaysia}

In Malaysia, import substitution was also the dominant strategy from the 1950s until about 1970, although trade barriers were significantly lower than in other 
developing countries. The average effective rate of protection was around 7 percent, compared with a range of 25 to 92 percent in other economies at a similar level of development (World Bank 1993:134). One reason for the relatively mild protection was the colonial tradition of a liberal stance to trade and industry (Athukorala and Menon 1997:64), but the political structure of the country was also an important determinant. The majority ethnic Malays dominated politics but had relatively little economic power, whereas the ethnic Chinese controlled most modern sector activities but had little political power. The bias against agriculture was also less serious than in many other countries, because of the economic and political importance of the mining and plantation sector.

Although the aggregate economic performance during the 1960s was respectable, with average GDP per capita growing by around 3 percent per year (Linnemann 1987: 363), it failed to reduce the gaps in economic and political power between the different ethnic groups. The poverty of the majority Malay population did not fall much. The resulting ethnic conflicts that rocked Malaysia in 1969 led to a reappraisal of the country's development strategy, and the New Economic Policy (NEP) established in 1971 introduced a number of measures to promote growth with equity. The central objectives of the NEP were to eradicate poverty through employment generation, and to increase the economic power of ethnic Malays. Trade policies were instrumental in achieving the first objective, and were designed to promote exports of natural resources and labor intensive light manufacturing goods, such as textiles, footwear, and garments. The policies included the usual tax allowances and preferential credits, but the most significant export promotion measures were the establishment of several export processing zones and free trade zones during the 1970s, mainly to attract foreign investors. To achieve the second objective, Malay participation in business was promoted in two ways. First, there was a drive to expand the state-owned industrial sector, through the acquisitions of foreign firms and establishment of new companies, where Malays would hold most key positions. Second, ownership and employment quotas favoring Malays were introduced. Manufacturing firms with more than 25 employees were required to get a business license, which was not granted unless NEP ownership and employment guidelines were followed. Malays were also granted privileged access to subsidized credit, share ownership, and business opportunities in the private sector (Athukorala and Menon 1997:65).

The impact of the NEP was notable. With an average growth rate of 8 percent, GDP doubled between 1971 and 1980. Foreign investment inflows to the export processing zones grew rapidly and manufactured exports expanded at a rate of nearly 29 percent per year between 1971 and 1980 (Linnemann 1987: 369). By 1980, 70 percent of manufactured exports originated in the export processing zones. Yet, Malaysia remained primarily a raw material exporter: manufactures only accounted for 19 percent of total exports. The slow structural changes in industry and export composition were seen as a reason to promote state-owned heavy industry. The first step in this direction was the establishment of the Heavy Industries Corporation of Malaysia in 1980. The government provided the Corporation's initial capital of USD 57 million and guaranteed subsequent credits at subsidized rates, as well as protection from imports and favorable government procurement. Over the following years, the Heavy Industries Corporation set up several joint ventures with foreign firms, in areas like petrochemicals, iron and steel, cement, paper and paper products, machinery, building materials, and transport 
equipment. By the mid-1980s, Malaysia had 867 corporate public enterprises, more than a third of which were in manufacturing (Athukorala and Menon 1997:65). Altogether, they accounted for some 20 percent of GDP at the time.

However, a large share of the import substituting industry was inefficient. Alavi (1996:177) reports that there was "no evaluation and monitoring to ensure that the protected industries were performing well in terms of efficiency and international competitiveness", and nothing was done to lead import substituting industries to produce for export markets. Even with cheap credits and protection, the SOE sector was running at a loss. A "dualistic" industry structure had emerged, with a highly footloose (largely foreign-owned) export sector concentrated to the EPZs and an inefficient domestic market sector operating in a protected environment (Alavi 1996:177). The annual GDP growth rate fell to 4.5 percent for the 1980-1986 period.

Hence, by the mid-1980s, it was clear that the economic advances of the previous decade had come to an end. The increases in public expenditure caused by the promotion of heavy industry had led to growing budget and current account deficits, as well as mounting foreign debt. The necessary cuts in public expenditure had a contractionary effect on the economy, and both domestic and foreign private investment were stagnating. Consequently, the NEP was abandoned in 1986, and subsequent policies aimed to promote private investment and exports. State-owned enterprises were gradually privatized - the revenues from privatization amounted to nearly USD 10 billion during the period 1989-1995 - and trade liberalization accelerated significantly. As a result of these more market oriented policies, merchandise exports grew from about USD 16 billion in 1985 to over USD 70 billion in 1995. The average annual GDP growth rate during this period was close to 10 percent. A stronger emphasis on education and training in public policy also made it possible to gradually upgrade production into sectors with higher value added. This impressive performance was tempered mainly by a persistent current account deficit - caused at least partly by too offensive investment strategies - that reached nearly 9 percent of GDP in 1995. The dependence on foreign savings made Malaysia vulnerable to fluctuations in international financial markets, as the financial crisis showed after 1997.

\section{Thailand}

Thailand's trade policies during the period 1955-1970 were a mix of support to natural resource based exports and protection of import substituting industries. Tariff protection was moderate until the late 1960s, and the most important incentives to domestic producers were in the form of tax exemptions and other privileges administered by the Board of Investment. Nominal tariffs on consumer goods were in the range 25-30 percent and tariffs for machinery and intermediate inputs were generally between 15 and 20 percent, which was lower than in most other developing countries (World Bank 1993:140).

This relatively mild form of import substitution changed from the beginning of the 1970s, when tariffs on consumer goods were raised to a range of 30-55 percent in an attempt to encourage domestic industrialization. Since the tariffs on machinery and intermediates remained at a lower level, this translated into a significant increase in the effective protection of domestic consumer goods industries. Textiles, pharmaceuticals, and automobile assembly received particular attention, and the high trade barriers were 
often coupled with domestic content requirements. However, it is often pointed out that Thai policies were not designed to "pick winners" in specific industries. Instead, the Board of Investment preferences were extended over time to a wider and wider range of industries, and many of the incentives, including a duty drawback scheme, were also made available to exporters from the early 1970s. The approach has been characterized as "trawling with a large fishing net" rather than "using a rod and the right bait". To some extent, this was probably a conscious and pragmatic policy, given the limited ability and capacity of the Board of Investment to identify potential winners, but it is also likely that exclusive preferences have been difficult to implement because of the features of the political system, with many influential interest groups. One of the few systematic biases could be that the duty drawback schemes favored upstream producers. By allowing intermediates and raw materials to come in almost without protection, the policies may have hampered the development of a more flexible and deeper industrial base.

Thai manufacturing production grew at an apparently healthy rate of approximately 10 percent per year during the 1970s (Linnemann 1987: 299), but the second oil shock revealed some of the weaknesses of import substitution and caused serious balance-of-payments difficulties. In 1981, the country's trade policy was therefore reformed to increase the openness and export orientation of the economy. The exchange rate was devalued, import restrictions were simplified and reduced, and the Board of Investment shifted its objective from promoting import substituting industries to promoting labor intensive exports and inflows of foreign direct investment. The microeconomic incentives were largely the same as elsewhere in the region: tax exemptions, duty drawbacks, export processing zones, infrastructure investments, subsidized credit, marketing assistance, and so forth. Initially, many of these measures were designed to neutralize the various distortions caused by protectionism, but by the early 1990s, a more broadly based import liberalization had started, providing added stimulus to export production.

The effects of the increasing outward orientation were spectacular. Foreign investment inflows increased dramatically. Merchandise exports jumped from USD 7 billion in 1985 to over USD 56 billion a decade later. In 1995, three-quarters of Thailand's exports were manufactures. Concurrently, the per capita income rose from USD 800 in 1985 to over USD 3,000 in 1995. However, by pegging the Baht to the US dollar, Thailand allowed its real exchange rate to appreciate, with detrimental effects on export competitiveness in labor intensive industries. Insufficient public investment in education made the problem more severe, since the shortage of skilled labor precluded any attempt to move into higher value added sectors. These problems contributed to stagnating exports and a large current account deficit, exceeding 8 percent of GDP in 1995 and 1996. In combination with a collapsing real estate market and stock market which had experienced a boom when the appreciating real exchange rate reduced the expected return to investments in export oriented industry - this led to a financial crisis, pressure on the exchange rate, and a floating of the currency starting in mid-1997.

\section{China}

China is one of the most successful less developed countries in the last decade or two, reporting average GDP growth rates around 10 percent per year from 1980 to the late 1990s. Coupled with a low and falling rate of population growth, this has led to a 
doubling of per capita incomes within the last decade. The Chinese success has been the result of a gradual process of market development and outward orientation. The central elements of the Chinese economic miracle have been agricultural reforms, an increasingly important role for private firms and locally controlled township and village enterprises (TVEs), substantial inflows of FDI, and rapidly growing exports.

The reform process launched by Deng Xiaoping in 1978 was gradual and experimental. The agricultural sector was targeted first, with a dismantling of the collective farms as the major reform. The relative price of agricultural goods was also raised by about a quarter, and the combination of increased individual decision making power and higher prices sparked a strong output response. Output grew at an average rate of 6 percent per year during the period 1979-1989, and farm incomes grew quickly. Both consumption and savings in the rural household sector increased. This set the stage for an increase in rural industrial production, which took off in 1984, when a legal framework allowing TVEs was set up - purely private firms were legalized some years later. TVEs are rural industries that are owned, at least in principle, by a local government or collectively by members of a village or township. In most cases, the local governments provide financing for the enterprise, but do not interfere directly in management decisions so long as the managers contribute a negotiated amount to local funds. These enterprises compete with other firms, have reasonably hard budget constraints, and can go bankrupt if they do not cover their costs. Most are run by a manager who benefits if the firm makes profits, and is likely to lose his job if he does poorly.

The increasing role of TVEs and private enterprises, as well as significant inflows of foreign investment, helped spark an export explosion in China from the mid-1980s. Exports grew from less than USD 25 billion in 1980 to over USD 152 billion in 1995, most of which was accounted for by TVEs and firms with foreign investment. The annual export growth rate exceeded 10 percent during the 1980-1990 period, accelerating to over 15 percent during the first half of the 1990s. Aside from positive effects resulting from market orientation and private enterprise, the export boom was also driven by important reforms in trade and investment policy. The establishment of Special Economic Zones (SEZs) and open cities in China's southern coastal provinces was a particularly important step in the reform process. These regional reforms were in essence large scale experiments with trade and investment liberalization that were extending throughout the country after about a decade, when it was clear that they were highly successful in generating growth and development.

The targeting of specific geographical areas as bases for exports and foreign investment began already in 1979, when four SEZs were established in Southern China. These were Shenzhan, Zhuhai, and Shantou in Guangdong province, bordering to Hong Kong, and Xiamen in Fujian province opposite Taiwan. Together with 14 cities designated as "open cities" in 1984, the zones provided an export oriented environment for domestic as well as foreign investors, with tax allowances, lower tariffs, better infrastructure, more flexible labor markets, and less demanding bureaucracy. These preferences were largely made possible by a decentralization of decision-making power: regulations and decisions regarding investment, land use, labor policies, finance, taxation, and foreign trade were left to the jurisdiction of local administrations. By encouraging a concentration of domestic and foreign investment to the zones and open cities, the Chinese authorities were able to achieve economies of scale in the provision 
of infrastructure. The clustering of investment also generated economies of agglomeration, such as opportunities for investors to draw on a common pool of skilled labor and specialized services.

After a relatively cautious development during the first half of the 1980s, the SEZs were particularly successful in attracting investment from the neighboring Hong Kong and Taiwan, as well as from overseas Chinese investors in other countries. During the 1980s, the inflows of foreign direct investment to the SEZs reached over USD 4 billion. Spillovers from the zones also generated rapid growth in the surrounding provinces: industrial growth in Guangdong and Fujian was more than twice as fast as the national average during the 1980s. The positive demonstration effect of the SEZ experiment led to a diffusion of reforms to other parts of the country. In the late 1980s, foreign investors were allowed to set up wholly-owned affiliates outside the SEZs and a general wave of liberalization was adopted across China. Deng Xiaoping's tour of the coastal provinces in January 1992 - when he noted that "the color of the cat matters less than its ability to catch mice" - gave further momentum to the reform process. Almost all major cities and provincial capitals set up their own industrial zones with various incentives. The inflows of FDI to China increased dramatically during the following years, amounting to a total of USD 72 billion between 1992 and 1994. By 1992, firms with foreign investment already accounted for about a quarter of Chinese exports.

China has also attempted targeting specific industries, with mixed success. Starting in the early 1980s, the government promoted exports of light industrial products, textiles, and machinery and electronics by raising foreign exchange retention rights on export earnings. From 1985, firms participating in special "export networks" have also been guaranteed privileged access to electrical power and raw materials, as well as tax reductions on inputs. It appears that the impact on labor intensive exports has been positive, while the impact on heavy industry, i.e. machinery, is unclear. Machinery exports increased rapidly in the mid-1980s, but the growth was only temporary. Like in the other Asian economies, it has proven difficult to succeed with targeting of industries that are not based on existing comparative advantages.

Some mandatory export targets have also been applied, particularly on SOEs. Some 90 percent of Chinese exports are handled by state-owned foreign trade corporations that provide various preferences - particularly related to the supply of raw materials and other intermediates - to firms that meet their export targets. These preferences may be withdrawn if export targets are not met. It appears that this implicit threat of punishment has been an important factor in encouraging SOEs to engage in exports.

Finally, exchange rate policy has been an important ingredient of Chinese export promotion. Repeated devaluations had lowered the real effective exchange rate to about a third of its pre-reform level by the mid-1990s. This brought the prices of tradable goods in line with world market prices - gradually reducing the anti-export bias of the old, inward looking regime - and was also a crucial factor in maintaining the costcompetitiveness of Chinese goods in foreign markets. The period since the outbreak of the Asian crisis has seen a break with these policies, as China has chosen to maintain a fixed exchange rate to the USD. This may eventually cause problems for the country's export competitiveness, but has not been any major problem yet, largely because domestic prices have fallen during the past few years. 
The true test of the sustainability of the Chinese economic miracle is likely to come during the next few years, as China joins the WTO. The preparations for WTO membership have already contributed to a significant liberalization of trade barriers and capital controls. For instance, import tariff rates have been unilaterally reduced several times since the early 1990s, and various reforms have increased the degree of current account convertibility. This gradual liberalization has helped maintain the inflows of FDI at a high level until the present, at the same time as most other countries in the region suffered from shrinking capital inflows. Other structural strengths in the Chinese economy include high savings rates and access to world capital markets through Hong Kong, which allow China the option to raise vast amounts of foreign capital without relying on short term borrowing. The high standard of human capital is another important asset, with tens of thousands of students sent abroad for advanced studies each year. There are, however, also structural weaknesses that will complicate the entry into the world trading system. State-owned enterprises continue to operate at low efficiency, and reforms are difficult because of the powerful interest groups backing state industry. Although direct subsidies to state sector have largely disappeared, policy loans to medium and large SOEs continue and are likely to slow growth of the more competitive non-state sector. The most serious consequence may be a weakening of the banking system, which is burdened by large amounts of problem credits (particularly to SOEs), and which may eventually cause problems of the kind seen in the rest of East Asia during the late 1990s.

\section{Lessons and conclusions regarding export promotion}

Summarizing some of the experiences of export promotion policies in Asia, it is clear that the export booms underlying the Asian success stories did not generally occur spontaneously, as an inevitable result of the interaction between supply and demand in free markets. Instead, governments played a central role in the development process. Most significantly, periods of successful growth and export expansion were characterized by public policies providing a stable economic environment with various incentives for private business, and promoting the accumulation of human and physical capital. It is no coincidence that several of the economies discussed above exhibit remarkably high rates of savings, investment, and human capital accumulation. The policies implemented to achieve this growth oriented macroeconomic environment were quite orthodox. The GDP share of government spending and the level of taxation were relatively low. Strict fiscal and monetary discipline kept budget deficits, domestic and foreign debt stocks, and inflation rates sufficiently low to be manageable. Exchange rates were managed to avoid overvaluation of the domestic currency. The stability made it possible to avoid imposing general import restrictions to correct balance-of-payments deficits, and facilitated a gradual reduction of trade restrictions. In fact, trade liberalization was often integrated with macroeconomic management, so that major phases of liberalization coincided with devaluation, exchange rate unification, fiscal reform, and inflows of foreign aid or concessional loans to offset the temporary weakening of the current account (World Bank 1993). Both trade liberalization and realistic exchange rates were necessary requirements for export success, given that most exporting firms were dependent on access to imported intermediary and capital goods, and relied on low prices as a major competitive asset. Concurrently, land reforms were important in many countries to create a more equal distribution of income and wealth 
and to allow a larger part of the population to benefit from the new export and growth opportunities. In fact, most of these policies were not only beneficial for export performance, but rather for economic growth in general.

Looking more specifically at the policies and institutional framework in the export sector, it appears that the most successful episodes of export promotion share some common features. First, the allocation of various preferences and export incentives has largely been based on markets and competition: to qualify for continued support, firms have had to show good export performance. Strict discipline in the administration of supports has by and large preserved hard budget constraints. Firms that could not achieve their objectives were often forced to merge with others, or even forced out of business. Second, it is the private sector rather than state-owned that has been targeted and that has responded to the various interventions. In most countries, foreign investors have also played an important role for export success. Third, the governments have managed to carry out their policies, including the eventual reduction of state support, in an orderly fashion, without much interference from the interest groups involved and apparently without much corruption. In most countries, there have also been episodes when these characteristics have been weaker. Typically, the result has been instability and weaker economic performance - arguably, the Asian crisis is largely the result of failures on some or several of these points.

Regarding more specific export promotion policies, the following common elements can also be distinguished.

- Governments invested heavily in infrastructure. At the early stages of development, efforts focused on transportation networks - roads, railroads, port facilities - while investments in electricity and telecommunications were more important at later stages of the process. Investment in education was particularly important, and countries where human capital accumulation was slow have become trapped into low wage and low value added sectors.

- Exporters were given access to inputs and capital goods at world market prices. In most cases, this was achieved through tariff exemptions and duty drawback schemes, although nearly all countries also established special export processing zones or programs for in-bond manufacturing in order to reduce the amount of red tape.

- Exporters were given preferential access to capital and foreign exchange. In many cases, credit was also provided at lower interest rates. These measures were particularly important in economies with weak domestic banking systems. However, long run subsidization of capital has in some countries made economic growth unnecessarily investment intensive, with excessive indebtedness and vulnerability as a result.

- Various kinds of fiscal incentives, ranging from tax holidays to accelerated depreciation allowances, were used to encourage investment in new export areas. These measures are likely to be most important at the early stages of export development programs.

- Governments played an active role in developing new markets by establishing institutions specialized in marketing and research, and by disseminating information about foreign markets. Apart from the Japanese case, where the large 
trading firms established extensive international networks already before the Second World War, it is clear that access to information about foreign markets and technologies was the major weakness of potential export companies at the time policies shifted towards increasing export orientation.

- Governments were concerned about enhancing the reputation of the country's exports, and established regulations and licensing procedures to guarantee high quality.

Generally, these export promotion schemes were more successful when they were neutral, in the sense that all (or at least most) potential export industries qualified for the benefits. By avoiding selective interventions that aimed to pick winners, it was possible to reduce the amount of rent-seeking that firms and industries were prepared to invest in lobbying to be included among the lucky few. Moreover, general export promotion programs reduced the demands on policy makers that would follow on ambitions to pick winners.

Selective export promotion programs faced several different problems. A first obvious challenge was to identify the specific sectors that deserved promotion. On this point, it should be noted that targeting based on current comparative advantages is a more reasonable task than the identification of future comparative advantages. Apart from the difficulties inherent in predicting future supply and demand conditions (at home as well as abroad) the creation of "new" comparative advantages requires comprehensive and costly measures to develop factor supply, both when it comes to material inputs and labor skills. Yet, even if these tough requirements are met, failures are inevitable, as illustrated by the limited success of the targeting of heavy and chemical industries in Korea, Taiwan, and Malaysia, or the many failed MITI projects in Japan.

This introduces a second major challenge - to identify the unsuccessful projects at an early stage, and to manage to withdraw support as soon as the failures are recognized. Any export promotion (or industrial policy) program is more likely to fail if the targeted firms and industries are given soft budget constraints and kept alive with public support for long periods of time. Evidently, up to the 1980s, both the Japanese and the Korean administrations were relatively independent from various industrial interest groups, and more efficient than most others in setting strict limits on public support. In fact, flexibility in adjusting to new market conditions and ability to abandon failing and obsolete support schemes may explain more of the success of Japan and Korea than their superior skills in recognizing future growth industries. The severe problems faced by both these countries in the late 1990s are clearly related to excessive investment in specific sectors ("strategic" industries or real estate) and weaknesses in the institutional setup of "checks-and-balances" that might have slowed the flow of capital to sectors with weakening competitiveness.

\section{What can Europe's transition economies learn?}

While it may appear straightforward to summarize some of the common elements of East Asia's export and growth success, it is more difficult to distinguish the main lessons for Europe's transition economies. The reason is not only that there are significant differences between Central and Eastern Europe and East Asia, but also that 
today's international environment differs from that a few decades ago. As a result, it is hard to determine how the relative competitiveness of the European transition economies compare to that of East Asia in the 1960s and 1970s, and which of Asia's export promotion policies would be effective today. One the one hand, European labor is less abundant and wage costs are higher than they were in the individual East Asian economies at the time of their initial export booms. The political regimes in Europe are also less authoritarian and probably less well equipped to direct the development of trade and industry than the governments in countries like Japan, Korea, Indonesia, or China. On the other hand, the average level of education and infrastructure in Europe today is higher than it was in East Asia some decades ago, at least when measured in quantitative terms such as years of schooling or telephones per thousand inhabitants, compensating to some extent for the higher labor costs. The geographic distance to the main markets is shorter, and the Europe Agreements and WTO rules in combination guarantee a higher minimum level of market access for the transition economies than what the Asian miracle economies enjoyed in Japan, the US, or Europe.

The Europe Agreements, other international obligations and the commitments made in the accession process also restrict the policy choices of the European transition economies. ${ }^{6}$ For instance, adopting the European Union's acquis communitaire introduces strict competition policies, e.g. ruling out direct state intervention to support "national champions". WTO membership excludes the use of direct export subsidies. The most serious policy-related restriction in this context may be the ambition to fulfill the Maastricht criteria in order to qualify not only for EU membership but also for joining the euro-zone. ${ }^{7}$ The Maastricht criteria mandate low government budget deficits and stable nominal exchange rates - while the former is well in accordance with the lessons from Asia, the latter is not necessarily so. The reason to be cautious about the virtues of a fixed nominal exchange rate is the Balassa-Samuelson effect (Balassa 1964). It is likely that the increase in the relative productivity of tradables versus nontradables in the candidate economies will be higher than that in the developed member countries of the EU (as a result of technological convergence). This will raise the wage level and the price of non-tradables, resulting in rates of inflation that are probably not compatible with the Maastricht criteria. Maintaining a nominal exchange rate in this situation will lead to real appreciation and probably weaker export competitiveness, while containing the inflation may require contractionary monetary and fiscal policies

\footnotetext{
${ }^{6} \mathrm{~A}$ further step beyond the implementation of the Europe Agreements is the accession process. This process aims to facilitate the convergence of the transition economies to the legal and institutional framework of the EU. The Europe agreements and the accession process jointly set the rules for the gradual establishment of free mobility for goods, services, labor, and capital between the EU and the potential new members (although migration from the transition economies will remain limited for several years after EU accession). They also include commitments from the transition economies to approximate their legislation to that of the EU in areas that are relevant for the internal market, like competition policy and protection of intellectual property rights.

${ }^{7}$ The existing EU treaties and agreements do not explicitly spell out when new members are expected to join the euro-zone, or how the financial convergence process should be managed. Although there are differences between the transition economies, most appear to aim for relatively strict adherence to the Maastricht criteria as part of their accession strategy.
} 
that could inhibit growth. These problems may be particularly relevant for relatively resource poor open economies, like the European transition economies (Ito et al. 1999).

Against this background, there is obviously reason to be cautious in drawing up lessons for the European transition economies. It may therefore be appropriate to distinguish between three sets of policy experiences. First, there are some policy lessons that are clearly appropriate for the Central and Eastern European economies. Second, it is equally clear that there are also experiences that are neither appropriate nor applicable in a European context. The third category includes some policies that are highly desirable for export promotion, but not compatible with the policy convergence to the European Union.

\section{The lessons}

Regarding the positive policy lessons, it is useful to begin by emphasizing once again the importance of macroeconomic stability. It is uncontroversial to note that strict fiscal and monetary policies to maintain reasonably balanced public budgets, together with relatively low levels of foreign and domestic debt, are probably necessary to maintain a stable macroeconomic environment. It may also be necessary to restrict the GDP share of the public sector to reduce the distortionary effects of high tax rates. For most European transition economies, this makes up a significant challenge, considering the historical legacy of a completely dominant state sector. In particular, it has been pointed out that pension reform, replacing pay-as-you-go pension systems with systems based on individual pension savings accounts, will be needed to reduce the levels of current government spending (Sachs and Warner 1996). Other broad policies needed to establish a growth oriented macroeconomic environment, such as appropriate incentives for private entrepreneurship, broad land reforms, and public support to education, science, and technology, are of course also required.

Turning to the more specific export promotion policies, it is clear that an open and outward oriented trade regime is of central importance. A free-trade environment is useful both because it makes it easier to identify the economy's comparative advantages and because it gives exporters access to imported inputs at competitive prices. An open foreign direct investment regime is also important for export promotion - a major share of inward FDI in the transition economies is already focused on exports to the EU (Stern 1997). Moreover, recent research results indicate that the operations of foreign export-oriented affiliates may have a positive impact on the exports of local firms as well, through spillovers of technology, marketing, and management skills (Kokko et al. 2001). Neither of these policy areas is likely to cause any major problems for the European transition economies. Both the Europe Agreements and WTO membership set minimum standards for trade and investment openness, and several countries have already progressed well beyond these minimum standards.

Many of the microeconomic export promotion measures tested in Asia are also relevant for Central and East Europe. Discussing the export impediments for the Central and Eastern European economies, Cooper and Gács (1997) emphasize two main problem areas. First, they note that exporters typically lack competitive financing. Second, exporters lack information on foreign standards, regulations, and customer requirements. One reason for these deficiencies is that governments have paid little attention to developing the infrastructure for the export sector. In fact, Gács (1997: 323) 
concludes that "The East European governments seem to have given far less support for their exports than their international commitments allow". In particular, the institutions for export credits, and export insurance and guarantee schemes are weakly developed, and not much has been invested to establish permanent trade missions abroad. It is possible that the most important lessons from the East Asian experience are found in these two areas. While the public investments in export infrastructure and financing have been important, it is likely that the measures to augment the human capital base were even more critical for the region's export success. In particular, it is notable that several of the East Asian economies have established formal institutions for international marketing, market research, and technology diffusion. In countries like Japan, South Korea, and Taiwan, the efficiency of these institutions has been enhanced by comprehensive investments in education at all levels. This has not only made it possible to transfer foreign technology and knowledge to selected actors in the country, but also to diffuse it throughout the economy.

Two lessons regarding the implementation of various microeconomic export promotion measures stand out. It is essential to maintain strict discipline in the administration of the supports, to preserve the hard budget constraints for exporters. It also appears important to focus on broad and relatively general forms of support that are automatically available to all exporters that fulfill certain predetermined criteria. This reduces the rent-seeking and corruption that tends to follow more selective schemes, where the profitability of the individual company or group of companies is closely related to whether or not they qualify for public support.

The most important negative lesson from the Asian experience is related to selective large-scale export promotion. ${ }^{8}$ The heavy and chemical industries drive in South Korea in the 1970s and the efforts to create competitive high-tech export sectors in Southeast Asia in the 1990s demonstrate some of the costs that are likely to emerge. The risk for increased rent-seeking and corruption has already been mentioned. Another general problem is that of "picking winners". While it may be possible to set up strongly selective support programs that favor industries which have already demonstrated their competitiveness, it is more difficult to identify those industries that will become competitive in the future. Moreover, it is typically very difficult to maintain hard budget constraints in these "strategic industries". The introduction of various subsidies is often interpreted as a signal that market prices do not matter - in heavily supported industries, it may also be understood that short-term nominal profits do not matter. The moral hazard involved is, in fact, likely to contribute to too much risky investment in the targeted sectors, resulting in excess supply and downward pressure on prices. In addition, it may be difficult to finance large targeted programs without introducing various kinds of distortions. The sectors that are not supported will face a heavier tax burden if the funds come from the government budget. Crowding out and weakening of the financial sector are likely if the funds are raised in the domestic credit market, with further complications if the policies are financed through foreign borrowing. It is clear that problems of these kinds contributed to the Asian crisis in the late 1990s (although weak financial institutions, speculative investments in real estate and other assets, and real appreciation of the regional currencies were probably more important).

\footnotetext{
${ }^{8}$ It is hardly necessary to note that direct export subsidies and other support measures that are not compatible with WTO rules could also be added to the list of negative lessons.
} 
The main item in the third category - policies that are desirable for export promotion but not compatible with the convergence towards EU standards - is exchange rate policy. Throughout East Asia, the exchange rate has been used actively from time to time to promote exports, and all major episodes of export orientation have started out with significant devaluations. High rates of export growth have been sustained as long as the productivity increases in industry have matched the real rate of currency appreciation. Problems have followed when the currencies have appreciated faster. The main example is again the Asian crisis. Most East Asian currencies appreciated significantly against the Japanese yen and other non-dollar currencies during the years before the 1997 crisis, either because the currencies were fixed to the appreciating US dollar or because large inflows of foreign capital strengthened the currencies. This reduced export competitiveness, diverted investment from the export industries to real estate and other local-market oriented sectors, and resulted in rising foreign indebtedness and current account deficits. Although the European transition economies are not likely to experience capital inflows of the magnitude seen in parts of Asia during the 1990s, similar worries are still relevant. A number of governments favor nominal exchange rate stability - in some cases, this is guaranteed through currency boards and all currencies have appreciated significantly in real terms during the past decade. This process is likely to continue in the future due to the unavoidable impact of the Balassa-Samuelson effect. It is hard to see how high and sustainable rates of (export) growth could be maintained in such a situation. Some degree of flexibility in exchange rate policies would therefore be desirable, in particular with reference to EU member countries that are outside the euro-zone like Denmark, Sweden, and the UK, where the attitudes to exchange rate stability have been less rigid.

There are many other areas where similar arguments against strict convergence to the EU standards are easy to make - the reason is simply that the present legal and institutional setup of the EU has not been established to maximize the growth rate of GDP or exports. For instance, Sachs and Warner (1996) argue that the transition economies should opt out of the EU's Social Charter in the short to medium run, to avoid burdening their relatively weak economies with the high social costs that are implied by full convergence. These concerns should of course be balanced against the potential benefits from full access to the Single European Market. The key question is to what extent these two perspectives can be combined. The most likely answer is that new members will probably not be allowed to deviate significantly from the EU standards, in particular when the common rules concern competition in the Single Market.

In summary, it can therefore be argued that the Central and Eastern European transition economies will probably not be able to duplicate all of East Asia's growth and export promoting policies. This is likely to mean that their short to medium term export performance may not quite match that of the Asian Tiger and Dragon economies some decades ago, although the export sector will still play a central role for growth and convergence. The relevant lessons from the Asian miracle economies point to the importance of sound macroeconomic policies and some of the "softer" forms of export promotion. These include public investment in infrastructure and investments in institutions to support export financing and insurance, market research, dissemination of information about foreign market opportunities, training and education in export-related skills, and technology transfer. 
The lessons from Asia also throw doubt on some of the ambitions to converge rapidly to EU standards. In particular, there is reason to be cautious regarding the objective to fix the nominal exchange rate during periods of relatively high growth. 


\section{References}

Alavi, R. (1996), Industrialisation in Malaysia: Import substitution and infant industry performance, Routledge; London and New York.

Athukorala, P. and J. Menon (1997), "Export-Led Industrialisation, Employment and Equity: The Malaysian Case", Agenda, Vol. 4 (1), 63-76

Balassa, B. (1964), “The Purchasing Power Parity Doctrine: A Reappraisal”, Journal of Political Economy, Vol. 72, 584-596.

Buckley, R. (1998), Japan Today, Cambridge University Press, New York and Melbourne.

Chang, H.J.(1993), "The Political Economy of Industrial Policy in Korea", Cambridge Journal of Economics, Vol. 17 (2), 131-157.

Cooper, R.N. and J. Gács (1997), "Introduction and Summary", in R.N. Cooper and J. Gács, eds., Trade Growth in Transition Economies: Export Impediments for Central and Eastern Europe, Edward Elgar; Cheltenham.

Das, D. (1996), "An Introduction to the Japanese Economy", in D. Das, ed., Emerging Growth Pole: The Asia-Pacific Economy, Prentice Hall; Singapore.

Doi, N. (1989), "Enterprise Groups and Market Performance in Japanese Manufacturing Industries", Rivista Internazionale di Scienze Economiche e Commerciali, Vol. 36 (2), 143-53.

Flath, D. (2000), The Japanese Economy, Oxford University Press; Oxford.

Gács, J. (1997), "Government Policies in Support of Exports in Small Transition Economies", in R.N. Cooper and J. Gács, eds., Trade Growth in Transition Economies: Export Impediments for Central and Eastern Europe, Edward Elgar; Cheltenham.

Greenaway, D. and C. Milner (1993), Trade and Industrial Policy in Developing Countries, Macmillan; London.

Hill, H. (1996), The Indonesian Economy since 1966: Southeast Asia's Emerging Giant, Cambridge University Press; Cambridge.

Ito, T., P. Isard, S. Symansky (1999) "Economic Growth and Real Exchange Rate: An Overview of the Balassa-Samuelson Hypothesis in Asia", in Changes in Exchange Rates in Rapidly Developing Countries: Theory, Practice, and Policy Issues, NBER-East Asia Seminar on Economics, vol. 7. University of Chicago Press: Chicago.

Kokko, A., R. Tansini and M. Zejan (2001), "Trade Regimes and Spillover Effects of FDI: Evidence from Uruguay", Weltwirtschaftliches Archiv, Vol. 137 (1), 124149.

Johnson, C. (1982), MITI and the Japanese Miracle, Stanford University Press; Stanford. 
Kuo, S.W.Y. (1988), "Development of the Taiwan Economy", in Conference on Successful Economic Development Strategies of the Pacific Rim Nations, ChungHua Institute for Economic Research Conference Series No. 10, Taipei.

Linnemann, H., ed. (1987), Export-Oriented Industrialization in Developing Countries, Singapore University Press; Singapore.

Moon, C (1994), "Changing Patterns of Business Government Relations in South Korea", in A. MacIntyre, ed., Business and Government in Industrialising Asia, Allen and Unwin; Sydney.

Ozawa, T. and M. Sato (1989), "JETRO, Japan's Adaptive Innovation in the Organization of Trade", Journal of World Trade, Vol. 23 (4), 15-24.

Republic of China (1990), Taiwan Statistical Data Book 1990, Council for Economic Planning and Development: Taipei.

Sachs, J. D. and A.M. Warner (1996), "Achieving Rapid Growth in the Transition Economies of Central Europe", Working Paper No. 116, Stockholm Institute of East European Economics.

Sakoh, K. (1984), “Japanese Economic Success: Industrial Policy or Free Market?”, Cato Journal, Vol. 4 (2), 521-543.

Stiglitz, J. (1996), "Some Lessons from the East Asian Miracle", The World Bank Research Observer, Vol. 11, pp. 151-176.

Stern, R. E. (1997), "Foreign Direct Investment, Exports, and East-West Integration: Theory and Practice", in R.N. Cooper and J. Gács, eds., Trade Growth in Transition Economies: Export Impediments for Central and Eastern Europe, Edward Elgar; Cheltenham.

Suh, C. S. (1996), "Korea in the 1990s: Little Dragon or New Giant?", in D. Das, ed., Emerging Growth Pole: The Asia-Pacific Economy, Prentice Hall; Singapore.

The Economist, various issues.

Thomas, V., J. Nash, and associates (1991), Best Practices in Trade Policy Reform, Oxford University Press for The World Bank; New York.

Trezise, P. H. (1984), "Japanese Economic Success: A Comment”, Cato Journal, Vol. 4 (2), 545-586.

Tsurmi, Y. (1980), Sogoshsoha: Engines of Export-Based Growth, Institute for Research on Public Policy; Montreal

Tsuru, S. (1993), Japan's Capitalism: Creative Defeat and Beyond, Cambridge University Press; Cambridge.

Westphal, L. E. (1978), "The Republic of Korea's Experience with Export-Led Industrial Development”, World Development, Vol. 6 (3), 347-82.

World Bank (1993), The East Asian Miracle: Economic Growth and Public Policy, Oxford University Press for the World Bank; New York.

Woo, W. T., S. Parker, and J.D. Sachs (1997), Economies in Transition: Comparing Asia and Eastern Europe, MIT Press; Cambridge, Mass. 